\title{
腰部脊柱管狭窄症の臨床像と保存療法について
}

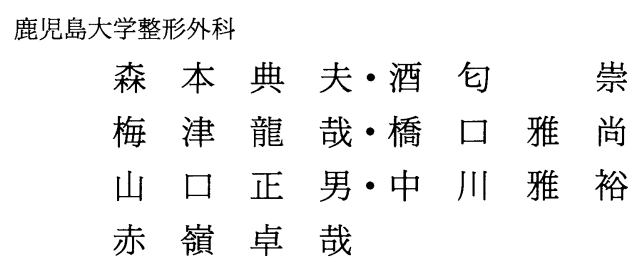

\section{Clinical Features of Lumbar Canal Stenosis and Conservative Treatment by}

\author{
Norio Morimoto, Takashi Sakou, Tatsuya Umezu, \\ Masanao Hashiguchi, Masao Yamaguchi, Masahiro Nakagawa \\ and Takuya Akamine
}

Department of Orthopaedic Surgery, Faculty of Medicine, Kagoshima University, Kagoshima

\begin{abstract}
Clinical features of lumbar canal stenosis were studied in 319 cases of our clinic in the last five years. There were 210 male and 109 female. The age varied from 22 to 88 (60.4 years on an average). Most of the patients were of degenerative type.

Subjective symptoms were various, but mainly low back pain (89\%), intermittent claudication and leg pain, and dysfunction was found in $29 \%$.

As the objective signs, Lasegue's sign and femoral stretching test were positive in $27 \%$ and $31 \%$ respectively, and sensory deficit in the leg and sensory deficit in more than 50\%. Epidural block was effective in $58 \%$ of the patients for relief of low back pain and intermittent claudication.
\end{abstract}

腰部脊柱管狭窄7) は, 先天性あるいは後天性に脊柱管 が狭小化し，馬尾や神経根が脊柱管あるいは lateral recess, 椎間孔で骨性, 軟部組織性に圧迫, 絞扼されて いる状態であり，その病態は複雑である，脊柱管狭窄 が単に存在するだけの解剖学的因子のみでは症状発現 には結びつかず, 動的因子, 化学的因子などの諸因子 が関与して症状が出現する。本症はその複雑な病態を 反映してきわめて多彩な臨床像を示す，今回，著者ら は保存症例, 手術例 319 例の本症について臨床像を明 らかにするとともに保存療法についても検討を行なっ た.

\section{対象および症例}

保存例 210 例, 手術例 109 例で男性 210 例, 女性 109 例と男性がほぼ 2 倍の頻度にみられる。初診時あるい は手術時の年令は 22 才より 88 才, 平均 60.4 才である.
保存例, 手術時の平均年令はそれぞれ 61.9 才, 57.7 才 で保存例がより高令である. 年令別では 50 才, 60 才代 にピークがある。職業別頻度では農業, 主婦, 会社員, 公務員などが主であった。

発症より手術あるいは初診までの期間は，1 カ月よ り 34 年, 平均 3 年 8 カ月であり, 本症の症状が慢性に 経過し長期間を経て受診あるいは手術に至ることがわ かる. 手術例の国際分類別 ${ }^{1)}$ では変性性, 分離之りの罹 病期間が長い。

\section{I . 全症例の臨床症状}

初発症状は圧倒的に腰痛が多く $60.6 \%$ を占めるが, これは諸家 ${ }^{233556)}$ の報告とほぼ一致している。下肢痛, 下肢のしびれがそれぞれ $27.1 \%, 22.4 \%$ にみら, 間 歇性跛行は $3.2 \%$ と少ない. 肛門周囲熱感により発症 したものが 1 例ある. 主訴は腰痛, 下肢痛, 下肢のし びれなどが大部分を占め, 間歇性跛行を主訴とするも 


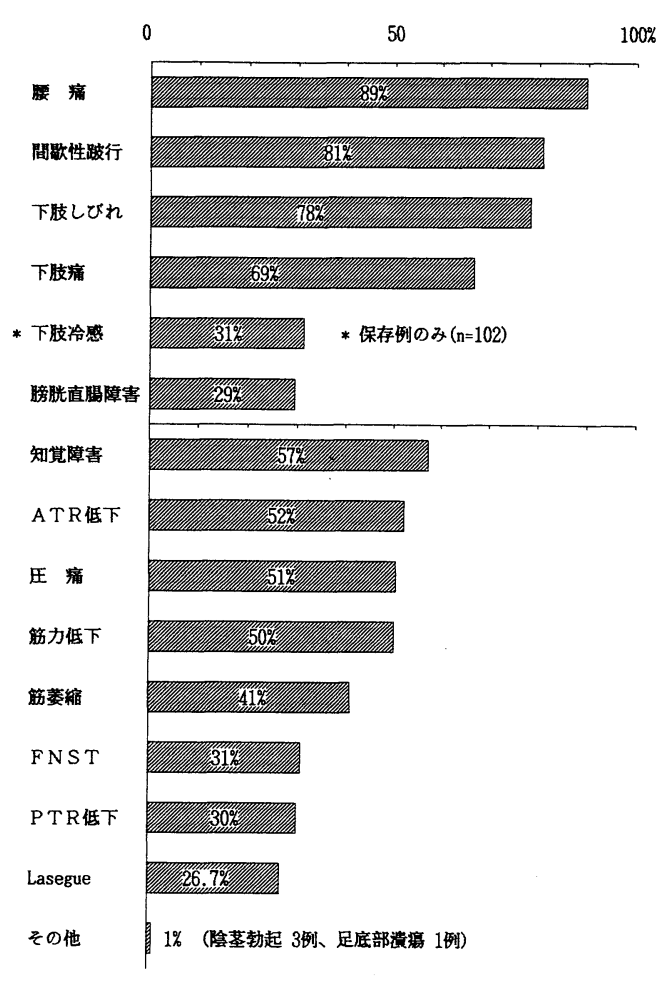

図 1 全症例の臨床症状（初診時）

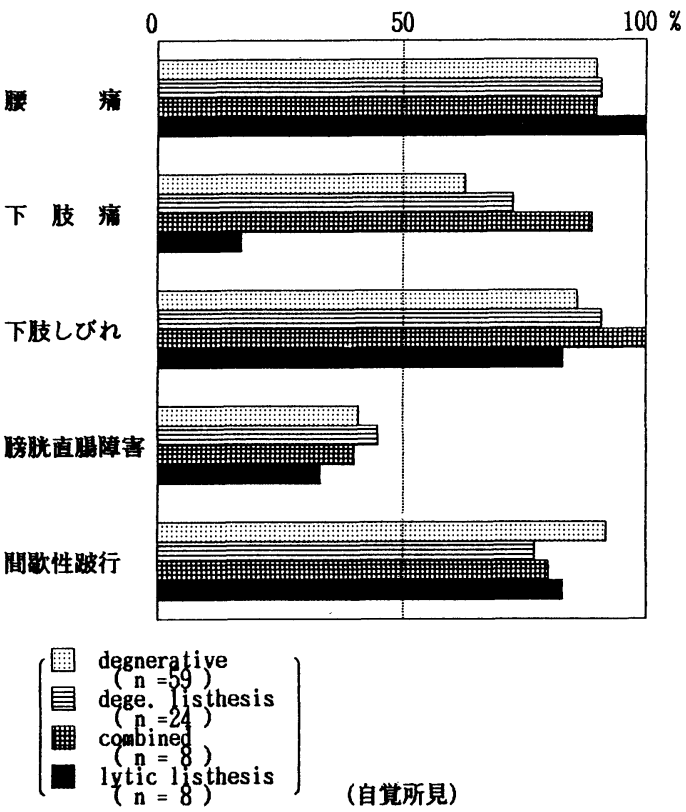

のは $20.8 \%$ と少ないが, 問診で有無を聞くことで判明 することが多い. 陰茎勃起を主訴とするものが 1 例み られた。

自覚症状については腰痛が約 $90 \%$ と圧倒的に多く, 間歇性跛行も $80 \%$ 以上に認められる.下肢冷感は保存 例 102 例のうち 33 例, $31.3 \%$ にられ, 膀胱直腸障害 も $30 \%$ 近く認められている.他覚所見は一般に乏しい といわれるが, 著者らの調査では知覚障害 $(57.2 \%)$, 傍脊柱筋や上慰神経部の圧痛 $(50.6 \%)$, 筋力低下 (50.2\%)がそれぞれ $50 \%$ 以上あり，またATR の低 下も $52.2 \%$ と高率に認められている。一方, femoral nerve strech test (30.9\%) や Lasègue 幑候 (26.7\%) は比較的少なく, まれな例として陰茎勃起が 3 例, 足 底部の難治性潰瘍が 1 例にみられている。（図 1 )。

本症に特有の間歇性跛行 ${ }^{8)}$ は, 歩行や諸動作により増 強するが, その性状はピリピリ感, じんじん感, チク チク感, 蟻走感などの色々の表現がなされている.こ のような感覚を伴った下肢痛が 91 例 $(69.7 \%$ )にみら れ, 筋力低下や giving way と形容される脱力 (感) が $13 \%$ に認められた. 本症に特徵的な sensory march は 187 例中 137 例, $73.3 \%$ にあり, 下行性が 128 例と圧 倒的に多い. 間歇性跛行はほとんどの症例で $100 \mathrm{~m}$ 以 内で出現するが, degenerative (spondylolisthesis も

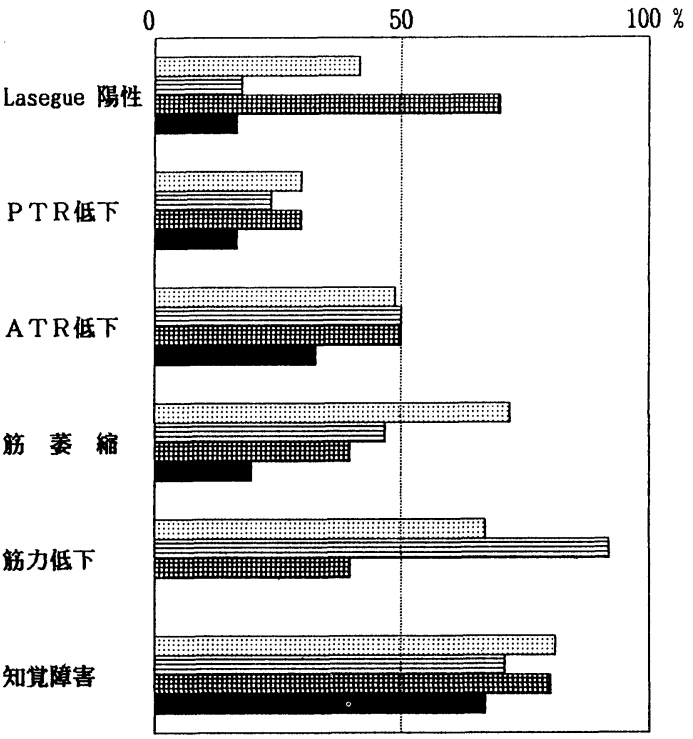

（他堂所見）

図 2 国際分類別臨床症状（手術例） 
含む), lytic spondylolisthesis では 400〜500 m で生ず るものが $30 \%$ 程度に認められる。

II. 手術症例における臨床症状

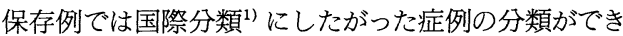
ないので，各タイプ別の臨床症状を比較するために手 術例 109 例について述べる. 症例数は listhesis を含め た degenerative stenosis が $76.9 \%$ と大半を占める。 各タイプの平均年令は当然のことながら degenerative type がもっとも高く (平均 60.6 才), combined (平均 48.6 才), post fusion (平均 46 才), lytic spondylolithesis (平均 53.6 才) は比較的低い.

手術例の自覚症状は腰痛，間歇性跛行，下肢しびれ とも保存例に比し，やや高率で，いずれも $84 \%$ 以上に 認められる.膀胱直腸障害は $46.7 \%$ と保存例のほほ 2 倍の頻度である．他覚的には知覚低下 $(78.4 \%)$, 筋力 低下 $(64.7 \%)$ ，筋萎縮（61.1\%) など高率にみられ， Lasègue 徴候も $40 \%$ 近くに達する。

次に臨床症状が国際分類の各夕イプ別にどのような 特徵を示すかみてみると, 腰痛は lytic listhesisに, 下 肢痛，下肢しびれは combined type, 跛行は degenerative typeにそれぞれ高率にみられるようである。 Lasègue 徵候陽性は combined type にもっとも多く, 筋萎縮は degenerative type に顕著である。筋力低下 は lytic listhesisにはみられなかった. PTR, ATR, 知覚障害には明確な差は認められない（図 2 ).

III. 保存療法について

本症の保存療法は, 筆者らはへルニアを合併した com bined type など，症例を選んで，牽引療法を行ない， 一般には caudal block を施行している.牽引療法には 80 例中 12 例（15\%）に何らかの改善をみ，有用な場 合もある。一方， caudal blockについては，102 例を 対象とし生食, 局麻剤，ステロイドの混注を行った。

その結果間歇性歩行で $58 \%$, 腰痛, 下肢痛およびし びれに対してもそれぞれ $56 \%$ ，51\%と 50 \%以上に改 善, 消失が認められ, 他賞的にも Lasègue の消失, 改 善が $55 \%$ ，知覚障害には $43 \%$ に消失，改善が得られ たが，筋力低下に対してはほとんど効果はなかった。 本症に対する保存療法は一般にさほど効果がないと考 えられているが,筆者らの経験では candal block で 50 \%以上，また永田ら ${ }^{4)}$ をはじめ諸家の報告した選択的神 経根ブロックでも $50 \%$ ～70\%程度の改善が得られてお り，永続的効果は期待できなくとも試みるべき療法と 思われる，次に間歇性跛行に対する薬剤の治療効果を
みるため, 51 例の症例に対し, 生食単独, 生食十局麻 剂, 生食十ステロイドの 3 群に分け，ブロックを行な ったところ, 生食十ステロイドが 22 例中 14 例 $(64 \%)$ と最も効果があった。一方, 生食単独, 生食十局麻剂 の効果は低率であった，この治療成績をサーモグラフ イーを用いて観察したところ, 跛行の改善度と皮膚温 の上昇との間に相関関係があり, 生食十ステロイド群 がもっとも有効であった。したがって間歇性跛行に対 するステロイド作用は抗炎症作用とそれに伴なう下肢 血行改善が考えられた。このことから類推すると，間 歇性跛行の発症機序として交感神経を含む神経根部の 炎症や下肢血行状態などの関与の可能性が推察される.

\section{ま と め}

1. 腰部脊柱管狭窄症の保存例, 手術例 319 例の臨 床像を検討した。

2. 初発症状は腰痛が圧倒的に多い.

3. 自覚症状では腰痛, 間歇性跛行, 下肢しびれが 高頻度に出現. 膀胱直腸障害も約 $30 \%$ \%られた。

4. 他覚的には Lasègue 徵候や F. N. S. T.の頻度 は低く, 一方, 知覚障害, 圧痛, 筋力低下, ATR 低下 などは $50 \%$ 以上に認められた。

5. 国際分類の各タイプ別での臨床像の明確な特徴 は認められなかった。

6. 本症に対する牽引療法は, 有効率 $15 \%$ で余り効 果なく, 硬膜外ブロック療法は $58 \%$ の有効率であった。

\section{参 考 文 献}

1) Arnoldi, C.C., Brodsky, A. E.: Lumbar Spinal Stenosis and Nerve Root Entrapment Syndromes. Clin. Orthop., : 4-6, 1976.

2）蓮江光男, ほか：腰椎椎間狭小の種々相とその臨床的 意義一主として概念と分類について一. 整形外科, 25 ： 745-754, 1974.

3）河合伸也, ほか：腰部脊柱管狭窄症の臨床症状. 32 ： 720-726, 1981.

4）永田覚三，ほか：腰部脊柱管狭窄症に対する保存療 法. 臨整外, $1: 740-750,1976$.

5）富永積生：腰部脊柱管狭窄症. 臨床像：整形外科, Mook, $41: 93-108,1985$.

6）辻 陽雄，ほか：腰部脊柱管狭窄一その臨床像と病 態一。臨整外, $16: 598-612,1981$.

7) Verbiest, H.: A Radicular Syndrome from Developmental Narrowing of the Lumber Vertebral Canal. J. Bone Joint Surg. 36-B : 230-237, 1954.

8）若野紘一, ほか：腰部脊柱管狭窄症. 間歇性跛行：整 
形外科, Mook, 41:109-119, 1985.

追 加

角田整形外科 角田 信昭

高令者で手術が不可能な例，または希望しない例も 増加しており, その意味で保存的療法の必要性が増加 しつつもあるように思います。

また，そういった例を長期間 followしてみますと， どうしても手術をしなければならない例もありますが, 症状の後解・再発をくりかえし，日常生活に適応して いる例もあるようですのでそれらの見分けが，必要に も思われます。
質 問

愛媛労災病院 田口 敏彦

Caudal block の効果について, central type と lateral type の LCS で差がありますか.

\section{解 答鹿児島大学 森本 典夫}

Caudal block は保存例のみを対象とした。保存例は ミエロ,CTを行っていないため, central, lateral type に分類できず，したがって両者に差があったかどうか は言えない。 